\title{
Spatial arrangements of corn grown in Brazilian savanna conditions
}

\section{Arranjos espaciais de plantas de milho cultivado em condições de Cerrado}

\author{
Eduardo Lima do Carmo ${ }^{1}$; Antônio Germano Carpim Rocha²; Camila Jorge \\ Bernabé Ferreira $^{3 *}$; Luiz Fernando Ribeiro Junior ${ }^{2}$; Gustavo André Simon ${ }^{1}$; \\ João Vitor Alves de Sousa ${ }^{2}$; Dionízio Felício Vieira Neto ${ }^{2}$
}

\section{Highlights:}

When sown at the ideal time, the spacing reduction does not influence the corn crop.

Under favorable climatic conditions, the increase in the plant population of corn increases yield.

Reduction in interrow spacing in corn $(0.25 \mathrm{~m})$ is a promising alternative under unfavorable climatic conditions.

\begin{abstract}
The suitability of the spatial arrangement of corn is a tool capable of promoting better use of the agricultural environment, allowing the crop to express its yield potential. The objective of this study was to evaluate the agronomic performance of the AG 7098 VT PRO2 corn hybrid, in the municipality of Rio Verde - GO, cultivated in different spatial arrangements of plants and sowing times. The experiment was carried out in a randomized block design with five replications, in a 4 × 2 factorial scheme, using four plant populations $\left(45,60,75\right.$, and 90 thousand plants ha $\left.{ }^{-1}\right)$ and two interrow spacings $(0.25$ and $0.5 \mathrm{~m}$ ), and two sowing times (January 26 and February 15, 2017). Morphological characteristics, yield components, and grain yield were evaluated, since data from each sowing season were analyzed separately. In the first period, the population increase in up to 85 thousand plants ha ${ }^{-1}$ resulted in an increase of grain yield, since there was no effect of reducing the spacing between rows on the evaluated characteristics. The corn sown in the second period, spaced $0.25 \mathrm{~m}$ between rows, provided an increase in grain yield, demonstrating that the density of plants may be a promising alternative when the climatic conditions are less favorable to the development of the crop in the Brazilian savanna region.
\end{abstract}

Key words: Narrow spacing. Second crop. Sowing time. Sowing density. Zea mays.

\section{Resumo}

A adequação do arranjo espacial do milho é uma ferramenta capaz de promover melhor aproveitamento do ambiente agrícola, permitindo à cultura expressar seu potencial produtivo. Objetivou-se avaliar o desempenho agronômico do híbrido de milho AG 7098 VT PRO 2, no município de Rio Verde - GO, cultivado em distintos arranjos espaciais de plantas e épocas de semeadura. $\mathrm{O}$ trabalho foi conduzido em delineamento de blocos casualizados, com cinco repetições, em esquema fatorial 2 x 4 , em que se

\footnotetext{
1 Profs., Faculdade de Agronomia da Universidade de Rio Verde, UniRV, Rio Verde, GO, Brasil. E-mail: eduardo@unirv.edu.br; simon@unirv.edu.br

2 Discentes do Curso de Mestrado, Programa de Pós-Graduação em Produção Vegetal, PPGPV, UniRV, Rio Verde, GO, Brasil. E-mail: antoniocarpim@hotmail.com; luizferunai@hotmail.com; dion_vieira@hotmail.com; joao_vitor1992@hotmail.com.br

3 Pós-Doutoranda, Programa de Pós-Graduação em Produção Vegetal, PPGPV, UniRV, Rio Verde, GO, Brasil. E-mail: camilajbferreira@gmail.com

* Author for correspondence
} 
utilizou dois espaçamentos entrelinhas $(0,25 \mathrm{~m}$ e $0,5 \mathrm{~m})$ e quatro populações de plantas $(45,60,75$ e 90 mil plantas ha ${ }^{-1}$ ), em duas épocas de cultivo (26 de janeiro e 15 de fevereiro de 2017). Avaliou-se características morfológicas, componentes do rendimento e a produtividade de grãos, posto que os dados de cada época de semeadura foram analisados, separadamente. Na primeira época, o aumento da população em até 85 mil plantas ha ${ }^{-1}$ resultou em acréscimo da produtividade de grãos, uma vez que não houve efeito da redução do espaçamento entrelinhas para as características avaliadas. O milho semeado na segunda época, em espaçamento entrelinhas de $0,25 \mathrm{~m}$, proporcionou aumento da produtividade de grãos, demonstrando que o adensamento de plantas pode ser alternativa promissora em épocas, nas quais as condições climáticas são menos favoráveis ao desenvolvimento da cultura na região do Cerrado.

Palavras-chave: Adensamento. Cultivo de safrinha. Época de semeadura. População de plantas. Zea mays.

\section{Introduction}

Brazil has a prominent position in world agricultural production, reaching 129.8 million tons of soybean and corn in the 2017/2018 season (Companhia Nacional de Abastecimento [CONAB], 2018). Corn culture, in turn, is considered the best alternative in succession to soybeans, and this cultivation system is responsible for the largest agricultural economy in the Brazilian savanna (Ceccon, 2018).

Phytotechnical adjustments in the second season with corn are necessary to ensure that the plant expresses its potential yield. For that, it is necessary that the disposition of these in the field is carried out taking into account factors such as: soil fertility, climatic condition, genetic material used, among others. Several works in the literature report on the relationship between the spatial arrangement of plants and the corn yield (Torres et al., 2013; Kopper et al., 2017). However, the arrangement of plants in the crop can be altered by changes in population density, in the interrow spacing and, consequently, in the spatial distribution of plants in the row (Sangoi, Silva, \& Argenta, 2010).

The sowing density is defined by the final number of plants per unit area, observing and counting the factors that influence it, since its adjustment can interfere with crop yield. Souza and Soratto (2006) observed a relationship between sowing date and density, which, when adjusted, contributed to reducing the effect of climatic factors, which interfere in grain yield by influencing the interception of solar radiation, water, and nutrient absorption, in addition to intraspecific competition.

Several studies have shown that a reduction in the interrow spacing of corn cultivation from 0.90 $\mathrm{m}$ to $0.50 \mathrm{~m}$ promoted better light use by plants, greater weed control and, consequently, greater crop yield (Modolo, Carnieletto, Kolling, Trogello, $\&$ Sgarbossa, 2010). With the reduction of spacing, there is a decrease in the number of plants per linear meter and, consequently, less competition between them, observing a pre-established population. The adoption of even smaller interrow spacings has potential advantages for corn cultivation, as it allows for better spatial distribution by area and faster interrow closing; thus, reducing interspecific competition for environmental resources and favoring the sustainability of agricultural exploration of this culture (Schmitt, 2014).

Most areas sown with corn in the savanna, as they are mostly cultivated in a second season crop, are conditioned to a period of more restrictive climatic conditions to the development of the crop. Above all, the sowing season for a second crop of corn is considered one of the key factors for grain yield, which is gradually compromised as it is delayed. Thus, the spatial adequacy of corn plants according to the planting season can be used as an interesting tool to allow the best use of plants in the agricultural environment. 
With genetic improvements, new corn hybrids have become more precocious, with plants of lesser architecture, smaller length of the tasseling-grain filling period, and erect leaves (Foloni et al., 2014). These characteristics, theoretically, provide the possibility of changing the interrow spacing and the plant population without negatively impacting grain yield (Kopper et al., 2017). Therefore, readjustments of the corn plant arrangement are necessary, especially in the savanna region, since this region has restricted climatic conditions in the second crop season.

Possibly, the increase in the number of plants per hectare, associated with the decrease in interrow spacing in the savanna edaphoclimatic conditions, will translate into higher yields for the corn crop. In this sense, the objective was to evaluate the agronomic performance of a second season of corn grown under different spatial arrangements of plants and sowing times.

\section{Material and Methods}

This experiment was conducted in the field, in the second crop season of 2017, in the municipality of Rio Verde, Goiás, with coordinates $17^{\circ} 45^{\prime} 59.20^{\prime \prime}$ $\mathrm{S}, 51^{\circ} 2$ ' $15.01^{\prime}$ W, and an altitude of $837 \mathrm{~m}$, with flat terrain (less than $3 \%$ slope). The area in which the experiment was conducted was set aside under soil classified as a Latossolo Vermelho (Empresa Brasileira de Pesquisa Agropecuária [EMBRAPA], 2018). Before the installation of the experiment, soil analysis was carried out for chemical characterization in the $0-0.20 \mathrm{~m}$ layer (Table 1 ). The granulometric analysis of the soil showed 580, 80, and $340 \mathrm{~g} \mathrm{~kg}^{1}$ of clay, silt, and sand, respectively, belonging to the sandy loam textural class.

Table 1

Chemical characterization of the soil in the $0-0.20 \mathrm{~m}$ layer of the experimental area

\begin{tabular}{ccccccccc}
\hline $\mathrm{pH}$ & $\mathrm{MO}$ & ${ }^{*} \mathrm{P}($ Mehlich $)$ & $\mathrm{K}$ & $\mathrm{H}+\mathrm{Al}$ & $\mathrm{Ca}$ & $\mathrm{Mg}$ & $\mathrm{CTC}$ & $\mathrm{V}$ \\
\hline $\mathrm{CaCl}_{2}$ & $\mathrm{~g} \mathrm{dm}^{-3}$ & $\mathrm{mg} \mathrm{dm}^{-3}$ & $\mathrm{mg} \mathrm{dm}^{-3}$ & & $\mathrm{cmol}_{c} \mathrm{dm}^{-3}$ & & $\%$ \\
\hline 5.7 & 14 & 7.6 & 65 & 2.0 & 1.76 & 0.53 & 4.4 & 55 \\
\hline
\end{tabular}

$\mathrm{MO}=$ organic matter $\mathrm{CTC}=$ cation exchange capacity; $\mathrm{V}=$ base saturation .

The predominant climatic type in the region is Aw, that is, tropical with rains concentrated in the summer period and a defined dry season in winter. The annual averages of temperature and precipitation in the region are $23{ }^{\circ} \mathrm{C}$ and $1,500 \mathrm{~mm}$, respectively. The rainfall and temperatures observed during the experiment are shown in Figure 1. 


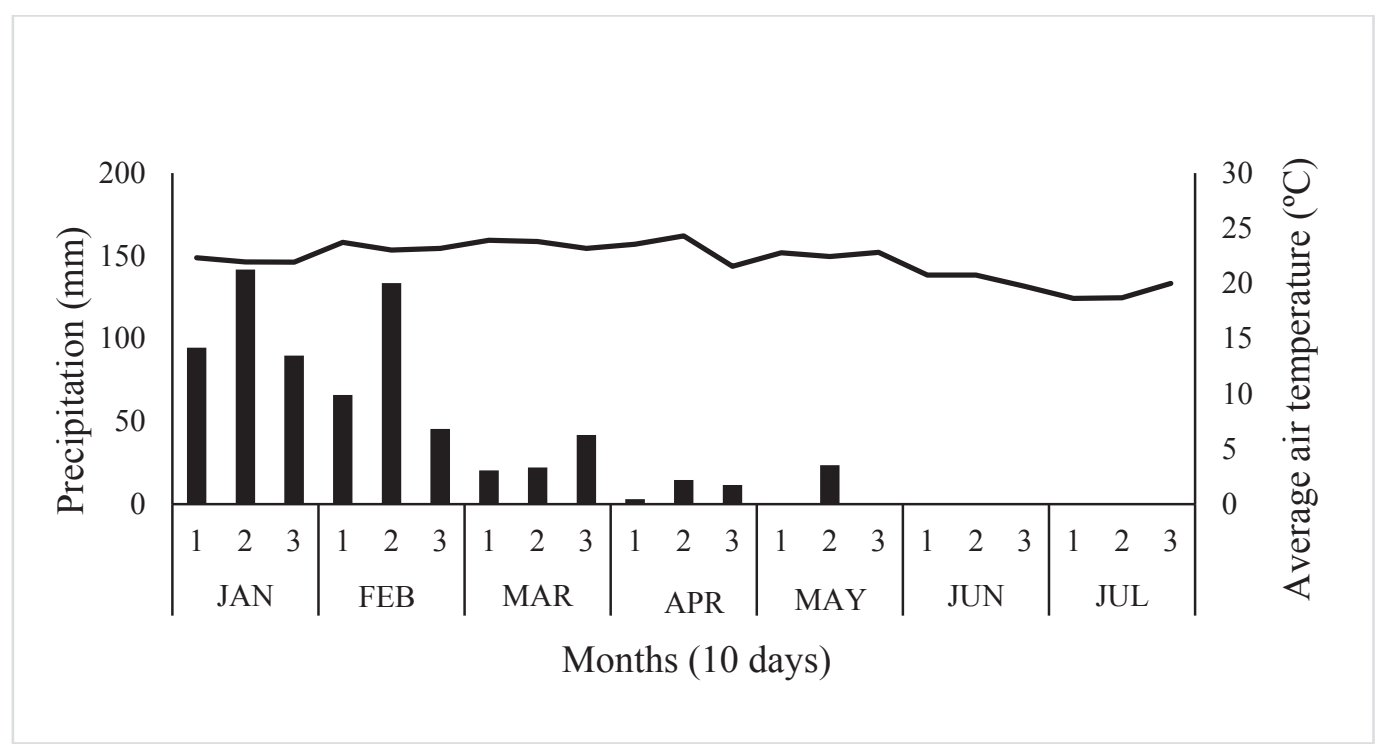

Figure 1. Precipitation and average air temperature during the second crop season 2017, Rio Verde (GO).

The work was installed in two periods. The first, on January 26 and the second on February 15, 2017. The experimental design used was randomized blocks, in a 4 x 2 factorial arrangement, with five replications. The first factor consisted of four plant populations: 45, 60 (recommended by the material's holder), 75, and 90 thousand plants $\mathrm{ha}^{-1}$. The second by the interrow spacings: $0.25 \mathrm{~m}$ and $0.50 \mathrm{~m}$ (thick and traditional, respectively).

In the $0.50 \mathrm{~m}$ spacing treatment, the experimental unit was composed of four rows of $5 \mathrm{~m}$ in length, the useful area being composed of the central rows, $0.50 \mathrm{~m}$ from each end being discarded $\left(4 \mathrm{~m}^{2}\right)$. In the $0.25 \mathrm{~m}$ spacing, the plot area was composed of seven rows of $5 \mathrm{~m}$ in length, and the usable area constituted by four centralized rows, disregarding $0.50 \mathrm{~m}$ at each end $\left(4 \mathrm{~m}^{2}\right)$. The hybrid used was AG 7098 VT PRO2 (early, tall, and sturdy stalked, which reduces lodging when there is variation in the plant population, according to the description of the holding company). The expressive cultivation area in the region was taken into account when choosing the hybrid.
Prior to the installation of the experiment, weeds were desiccated in the areas using $3.0 \mathrm{~L} \mathrm{pc} \mathrm{ha}^{-1}$ of the herbicide glyphosate $\left(1440 \mathrm{~g}\right.$ ea ha $\left.{ }^{-1}\right)$ and $0.8 \mathrm{~L} \mathrm{pc}$ $\mathrm{ha}^{-1}$ of 2,4-D (536 $\mathrm{g}$ ea ha-1 ${ }^{-1}$. Seed distribution was carried out by a continuous flow seeder mounted on a tractor's three-point hydraulic system, consisting of seven eccentric double sowing discs, regulated to distribute 120 thousand seeds ha-1 in both spacings.

Thinning was carried out on the tenth day after sowing, adjusting the population density to their respective experimental units. The sowing fertilization performed was $350 \mathrm{~kg} \mathrm{ha}^{-1}$ of monoammonium phosphate and $80 \mathrm{~kg} \mathrm{ha}^{-1}$ of potassium chloride. As coverage, $120 \mathrm{~kg} \mathrm{ha}^{-1}$ of nitrogen was applied, with urea being the source used, divided into two applications: the first at 15 days after emergence (DAE) and the second at 30 DAE. Twenty days after plant emergence, $2.5 \mathrm{~L} \mathrm{ha}^{-1}$ (1200 $\mathrm{g}$ ea $\mathrm{ha}^{-1}$ ) of glyphosate was applied to control weeds.

At the time of harvesting, the following evaluations of morphological characteristics were carried out within the useful area of each plot, 
evaluating ten continuous plants: plant height and ear insertion (measured from the ground to the peak of the male inflorescence, and from the soil to the insertion of the first ear, respectively), and stem diameter (measured with the aid of a digital caliper, positioned between the first and second stem knots in relation to the soil).

Ten ears were removed at random from each experimental unit to obtain the following characteristics: length and ear diameter, cob diameter, number of grains per row, number of rows per ear, and mass of grains per ear. After these evaluations, the remaining ears of the useful area were harvested. Samples were taken to determine the residual moisture and mass of 1,000 grains, and the weight of the samples were added to determine the grain yield in $\mathrm{kg} \mathrm{ha}^{-1}$, corrected to $13 \%$ humidity.

The data resulting from each sowing period were subjected to individual analysis of variance. When significant, the Tukey test at $5 \%$ probability was used to compare means involving the sowing spacing. Related to the different plant populations, regression analyses were performed.

\section{Results and Discussion}

In the first growing season, only the population had a significant effect on most of the evaluated characteristics, namely: plant height and ear insertion, stem and ear diameter, grain mass per ear, and grain yield (Table 2). However, in the second season, plant population had a significant effect on the characteristics: plant height and ear insertion, stem diameter, number of grains per row, mass of grains per ear, and mass of a thousand grains, while spacing between rows caused a significant effect on the variables: height of ear insertion, stem and ear diameter, ear length, grain mass per ear, and grain yield. The differentiated behavior of the variables in the different growing seasons indicates that the aforementioned choice influenced the behavior of the crop. The lack of response in the first season in relation to the interrow spacing, may be associated with the presence of a better water regimen in this period, a fact that reduces competition between plants for resources (Bergamaschi et al., 2006). 


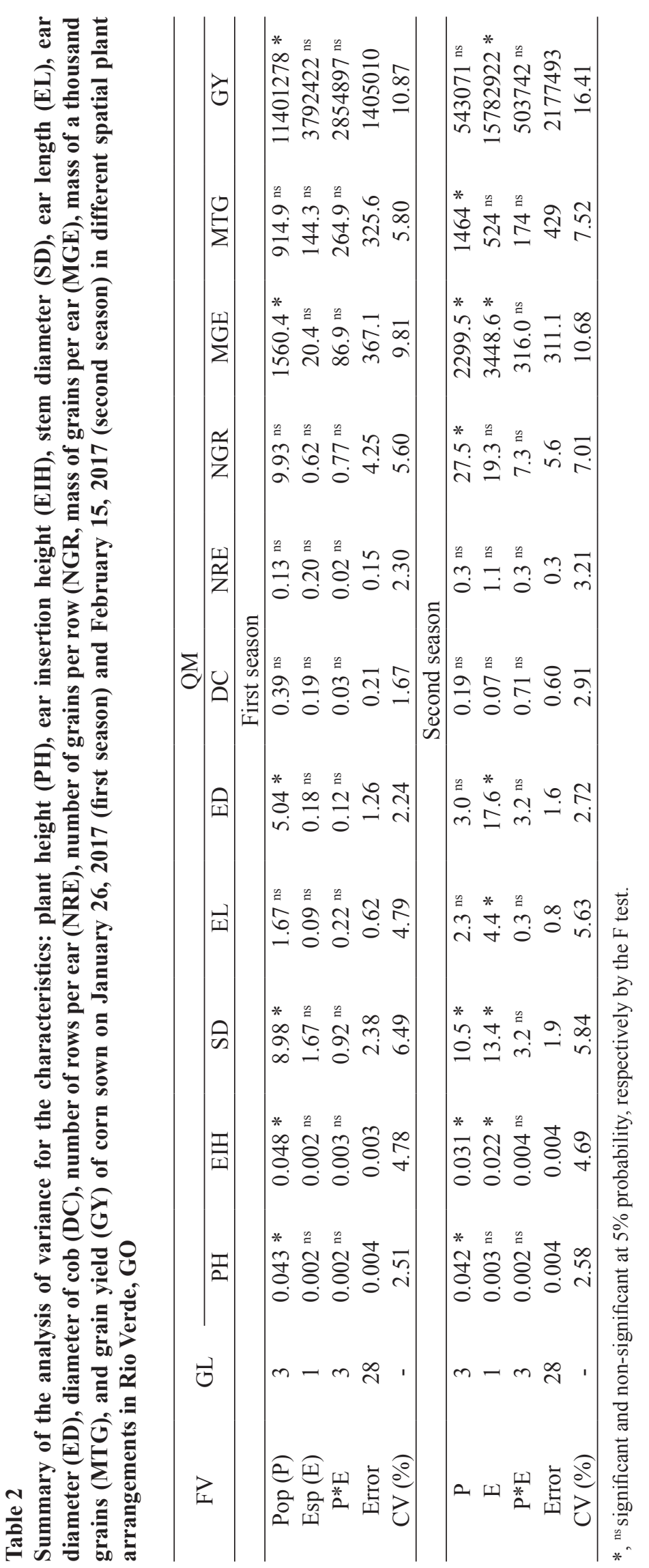


For both growing seasons, the height of corn plants had an upward trend with an increasing plant population (Figure $2 \mathrm{~A}, \mathrm{~B}$ ). The increase was approximately 7\%, comparing the smallest population (45 thousand plants ha ${ }^{-1}$ ) with the largest (90 thousand plants $\mathrm{ha}^{-1}$ ). This result is similar to that found by Marchão, Brasil, Duarte, Guimarães and Gomes (2005) and divergent from that of Foloni et al. (2014), who did not observe a relationship between plant height and populations of 39, 52, 79 , and 105 thousand plants ha-1. The height of ear insertion also increased with the increase of the population in both sowing times (Figure $2 \mathrm{C}$ and D), as it had a direct relationship with the height of plants due to elongation of the stem.

The stem diameter decreased with the increase of the plant population in both sowing times (Figure
2 E, F). With the increase in the plant population, greater vertical growth occurs due to competition for sunlight, as there is a reallocation of resources for faster growth, aiming to avoid shading, which favors a smaller stem diameter (Taiz \& Zeiger, 2017). Consequently, plants may be more sensitive to lodging, although it was not observed in this study. These results are in line with those obtained by Calonego, Poleto, Domingues and Tiritan (2011) and Silva, Teixeira, Martins and Simon (2014) who observed a decrease in stem diameter with an increase in the population of corn plants. Increased vegetative development, internode lengthening, and decreasing stem diameter are common responses of corn hybrids to an increase in plant population (Marchão et al., 2005; Kappes et al., 2011).

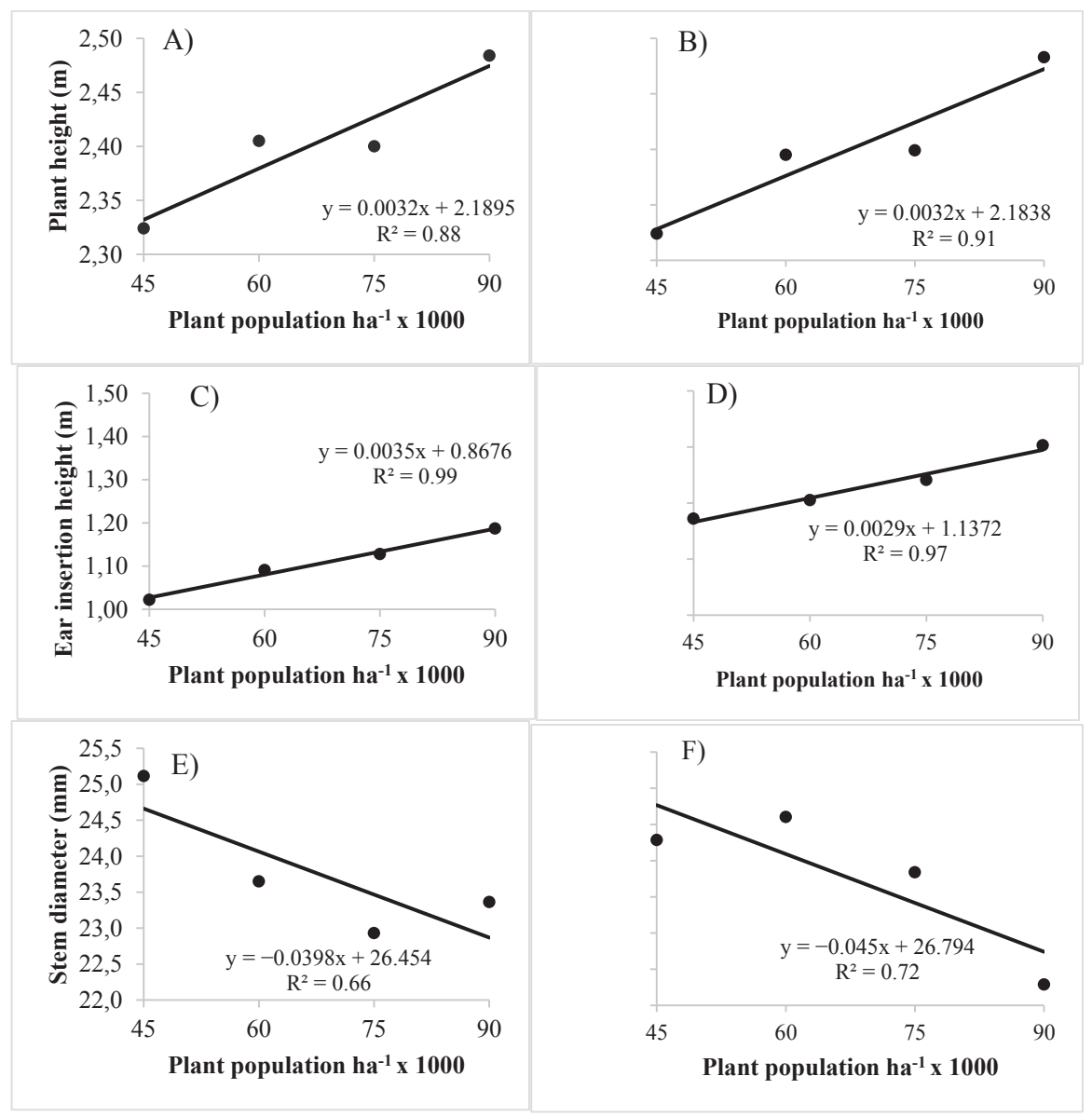

Figure 2. Plant height (A, B), ear insertion height $(C, D)$, and stem diameter $(\mathrm{E}, \mathrm{F})$ of corn sown on January 26 (A, C, E) and February 15 (B, D, F) of 2017 in different plant populations, Rio Verde (GO). 
In the first growing season (January 26, 2017), the ear diameter and grain mass per ear decreased with the increase in corn population (Figure $3 \mathrm{~A}$, B). This result can be associated with the increase in intraspecific competition that is reflected in a decrease in the availability of carbohydrates per unit of grain (Sangoi, Almeida, Ender, Guidolin, \& Konflanz, 2001).

Even with a smaller diameter and mass of grains per ear, in the first growing season, the corn yield grain grew with the increase of the population by up to 85 thousand plants per hectare (Figure $3 \mathrm{C}$ ), demonstrating that the increase in plant population, above that recommended (60 thousand plants ha${ }^{1}$ ), can be an interesting alternative when the crop finds favorable conditions to develop. The increase in yield was $8 \%$ (equivalent to $920 \mathrm{~kg} \mathrm{ha}^{-1}$ ) when comparing the recommended population with that of 85 thousand plants $\mathrm{ha}^{-1}$. Despite this advantage, it is important for the farmer to consider the costs involved in implementing a larger population.

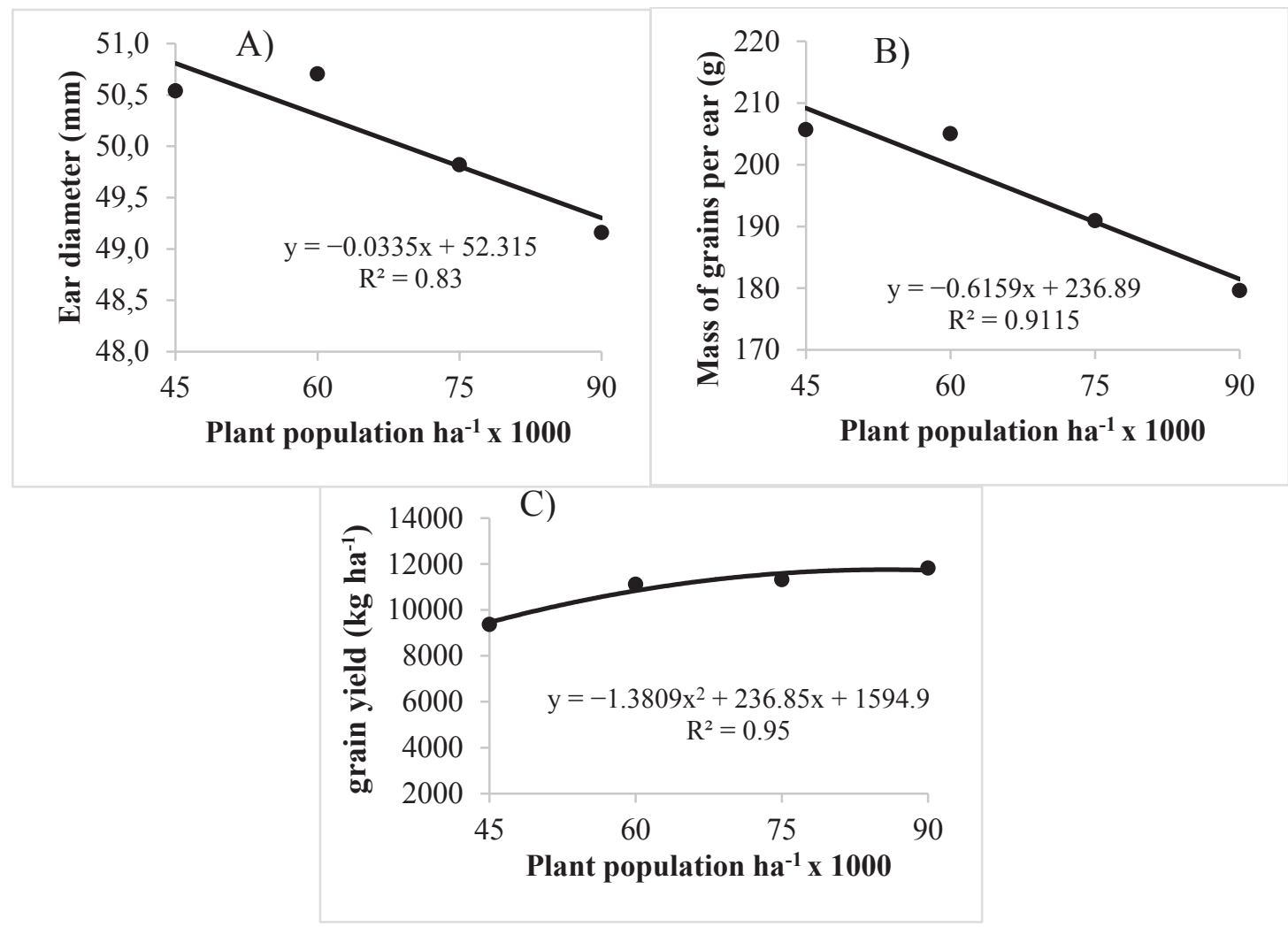

Figure 3. Ear diameter (A), grain weight per ear (B), and grain yield (C), of corn sown on January 26, 2017 in different plant populations, Rio Verde (GO).

Higher corn yield using a plant population above that recommended has also been reported by several other authors. For example, Kopper et al. (2017) found higher corn yield when the cereal was sown in a population of 70 thousand plants $\mathrm{ha}^{-1}$ (above that recommended). While Foloni et al. (2014) observed that the best yields were achieved with populations of 81 and 75 thousand plants ha-1 for hybrids AG 9010 and DKB 979, respectively, and both above the recommended population.

Despite these findings, in the second growing season (February 15, 2017), yield was not influenced by the plant population. This demonstrates the effect 
of climatic factors, which resulted in the increase in plant population not reflecting a greater gain in crop yield. This is because with the later sowing of corn, the interception of solar radiation and water availability decrease, consequently, the competition for environment resources increases (Souza and Soratto, 2006).
In the second growing season (February 15, 2017), the number of grains per row, mass of grains per ear, and mass of a thousand grains decreased linearly with the increase in plant population (Figure 4). This result was different from that found in a study conducted by Stacciarini et al. (2010), in which there was no significant difference in these characteristics.
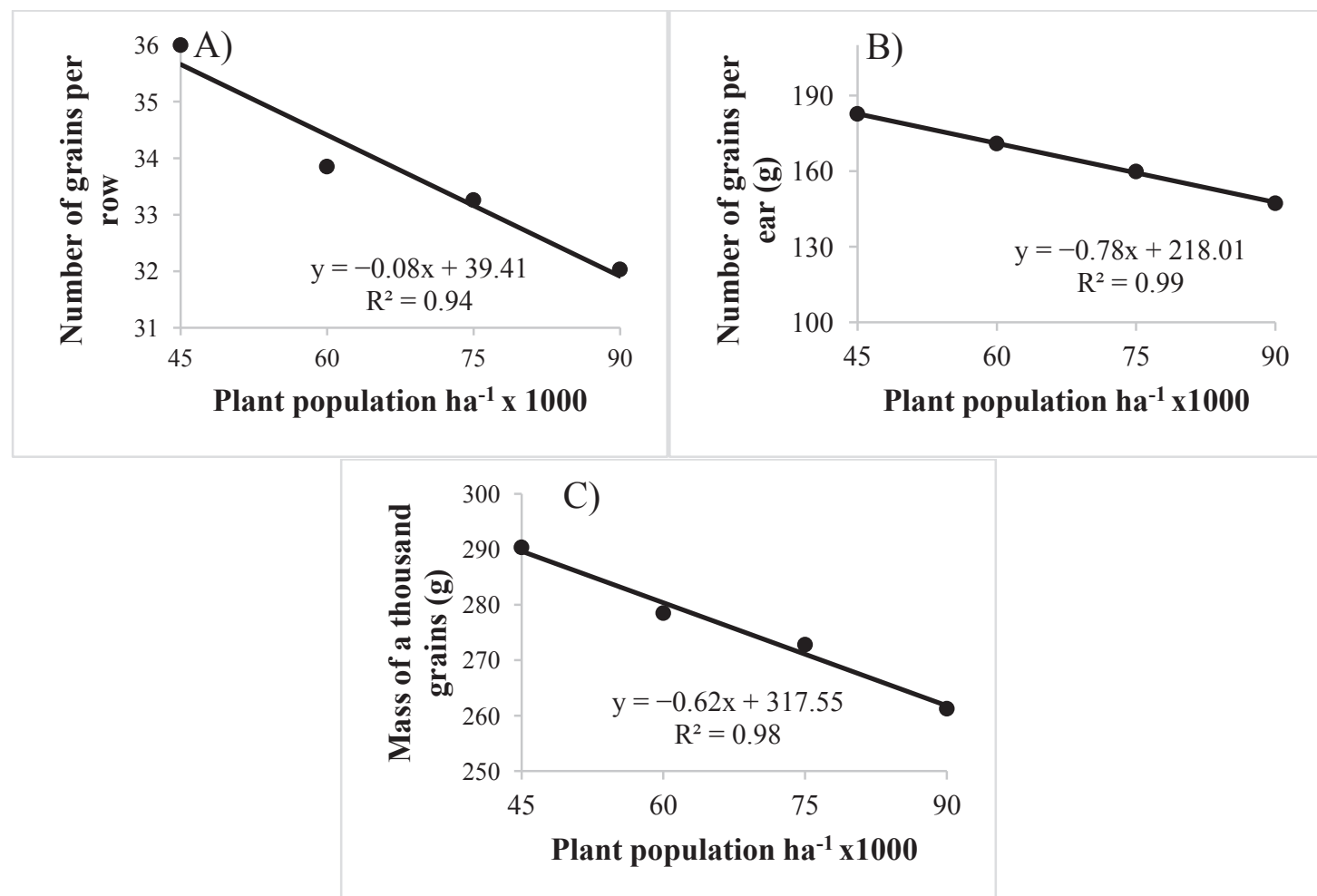

Figure 4. Number of grains per row (A), mass of grains per ear (B), and mass of a thousand grains (C), of corn sown on February 15, 2017 in different plant populations, Rio Verde (GO).

The reduction of interrow spacing from $0.50 \mathrm{~m}$ to $0.25 \mathrm{~m}$, for corn sown in the first season, January 26 , did not interfere in the agronomic characteristics evaluated. This result can be attributed to the fact that the environment was favorable to the development of the crop, to the point of not having significant changes in the plant's behavior. Some authors suggest that, even though the reduction in interrow spacing does not represent an increase in yield, this alternative constitutes a cultural practice for the management of weeds in corn, since they increase the competitiveness of the crop, and may reduce the use of herbicides (Gross, Von Pinho, \& Brito, 2006; Farinelli, Penariol, \& Fornasieri, 2012).

In the second sowing season, the denser spacing reduced the height of ear insertion and increased stem diameter (Table 3). With a larger diameter stem, and consequently greater reserve, the use of the $0.25 \mathrm{~m}$ spacing provided an increase in the length and diameter of the ears, producing a mass 
of superior ears in $12 \%$, compared to the interrow spacing of $0.50 \mathrm{~m}$. As a consequence, there was an increase in grain yield of $15 \%\left(1256 \mathrm{~kg} \mathrm{ha}^{-1}\right)$ using the densest corn plants $(0.25 \mathrm{~m})$. Johnson, Hoverstad and Greenwald (1998) explained that the reduction in interrow spacing provides greater efficiency in the interception of solar radiation and decreases competition in the sowing row in environments with less water and light availability, reflecting in a greater yield for the crop.
In situations in which some environmental resources (water, solar radiation, or nutrients) are scarce, the reduction of spacing has more pronounced effects on the crop yield, compared to situations in which the supply of resources is adequate (Barbieri, Rozas, Andrade, \& Echeverria, 2000). The sowing in spacing of $0.25 \mathrm{~m}$ in the second crop showed a response in yield, because at that time, the days were shorter and had lower levels of solar radiation benefiting the culture in this spacing, by providing better use of light by the distribution of plants in the area being more equidistant.

\section{Table 3}

Average values of agronomic characteristics of Agroceres 7098 corn hybrid, sown on February 15,2017 (second season) in different plant arrangements, Rio Verde, GO

\begin{tabular}{ccccccc}
\hline Interrow & \multicolumn{5}{c}{ Average* $^{*}$} \\
\cline { 2 - 6 } spacing (m) & EIH $(\mathrm{m})$ & $\mathrm{SD}(\mathrm{mm})$ & $\mathrm{EL}(\mathrm{cm})$ & $\mathrm{ED}(\mathrm{mm})$ & MGE $(\mathrm{g})$ & Grain Yield $\left(\mathrm{kg} \mathrm{ha}^{-1}\right)$ \\
\cline { 2 - 7 } $\mathbf{0 . 2 5}$ & $1.31 \mathrm{~B}$ & $16.26 \mathrm{~A}$ & $47.52 \mathrm{~A}$ & $17.25 \mathrm{~A}$ & $174.46 \mathrm{~A}$ & $9621.58 \mathrm{~A}$ \\
$\mathbf{0 . 5 0}$ & $1.35 \mathrm{~A}$ & $15.60 \mathrm{~B}$ & $46.20 \mathrm{~B}$ & $16.92 \mathrm{~A}$ & $155.88 \mathrm{~B}$ & $8365.28 \mathrm{~B}$ \\
\hline
\end{tabular}

$\mathrm{EIH}=$ ear insertion height; $\mathrm{SD}=$ stem diameter; $\mathrm{EL}=$ ear length; $\mathrm{ED}=$ ear diameter; $\mathrm{MGE}=$ mass of grains per ear. * Averages followed by the same letter do not differ significantly at $5 \%$ probability by the Tukey test.

The results obtained in this study indicate that, in late-season of corn sowing, where the possibility of water scarcity is more common, the use of the $0.25 \mathrm{~m}$ interrow spacing is an alternative that can be adopted by farmers in order to achieve greater grain yield. For this to happen, developing implements that allow the use of this technology to be feasible are necessary. Similar results were observed in soybean cultures, in which higher yield was observed in densified sowing when compared to traditional spacing (Moreira, Moraes, Schroth, \& Mandarino, 2015; Carmo, Braz, Simon, Silva, \& Rocha., 2018), although Balbinot, Procópio, Debiasi, Franchini and Panison (2015) observed greater yield using $0.6 \mathrm{~m}$ spacing when compared to $0.4 \mathrm{~m}$ in soybean cultivars of determined growth. With these findings, the possibility of a new alternative of management practice in the soybean/corn season production system opens up, increasing farmers' cultivation alternatives and consequently, the possibility of more profitable crops.

Thus, the importance of adjusting the spatial arrangement of plants in the corn culture grown in second crop season in the savanna region is noticeable, and they must be carried out according to the sowing time. In earlier sowing, it is interesting to use plant populations above that recommended for the corn hybrid AG 7098 VT PRO2. In addition, it opens up the possibility of using new technologies related to the dense cultivation $(0.25 \mathrm{~m})$ of corn when it is sown later. These facts are important for the studied region, since the climatic conditions in the second crop season are gradually restrictive, making adjustment in the spatial arrangement of plants a fundamental tool to optimize the capture of environmental resources and decrease competition for them. 


\section{Conclusion}

In early corn cultivation, during the second crop season, in which climatic conditions are normally more favorable, the increase in the plant population of the AG 7098 VT PRO2 corn hybrid above that recommended (60 thousand plants $\mathrm{ha}^{-1}$ ) increased grain yield up to 85 thousand plants ha ${ }^{-1}$.

The AG 7098 VT PRO2 corn hybrid sown later, in the second crop season, in $0.25 \mathrm{~m}$ interrow spacing, is a promising alternative in terms of grain yield, given the less favorable climatic conditions for crop development.

\section{Referências}

Balbinot, A. A., Jr., Procópio, S. O., Debiasi, H., Franchini, J. C., \& Panison, F. (2015). Semeadura cruzada em cultivares de soja com tipo de crescimento determinado. Semina: Ciências Agrárias, 36(3), 1215-1226. doi: 10.5433/1679-0359.2015v36n $3 \mathrm{p} 1215$

Barbieri, P. A., Rozas, H. R. S., Andrade, F. H., \& Echeverria, H. E. (2000). Row spacing effects at different levels of nitrogen availability in maize. Agronomy Journal, 92(1), 283-288. doi: 10.2134/ agronj2000.922283x

Bergamaschi, H., Dalmago, G. A., Comiran, F., Bergonci, J. I., Muller, A. G., França, S., \& Pereira, P.G. (2006). Déficit hídrico e produtividade na cultura do milho. Pesquisa Agropecuária Brasileira, 41(2), 243-249. doi: 10.1590/S0100-204X2006000200008

Calonego, J. C., Poleto, L. C., Domingues, F. N., \& Tiritan, C. S. (2011). Produtividade e crescimento de milho em diferentes arranjos de plantas. Revista Agrarian, 4(12), 84-90.

Carmo, E. L., Braz, G. B. P., Simon, G. A., Silva, A. G., \& Rocha, A. G. (2018). Desempenho agronômico da soja cultivada em diferentes épocas e distribuição de plantas. Revista de Ciências Agroveterinárias, 17(1), 61-69. doi: 10.5965/223811711712018061

Ceccon, G. (2018). Milho safrinha no Cerrado brasileiro. Revista Plantio Direto \& Tecnologia Agrícola, 162(1), 5-8.

Companhia Nacional de Abastecimento (2018). Séries históricas. Brasília, DF: Ministério da Agricultura, Pecuária e Abastecimento. Recuperado de http:
conab.gov.br/conteudo.php?a=1252\&Pagina objcmsconteudos $=3 \#$ A_objemsconteudos

Empresa Brasileira de Pesquisa Agropecuária (2018). Sistema brasileiro de classificação de solos. Rio de Janeiro: EMBRAPA Solos, Centro Nacional de Pesquisa de Solos.

Farinelli, R., Penariol, F. G., \& Fornasieri, D. F. (2012). Características agronômicas e produtividade de cultivares de milho em diferentes espaçamentos entre linhas e densidades populacionais. Cientifica, 40(1), 21-27. doi: 10.15361/1984-5529.2012v40n $1 \mathrm{p} 21+-+27$

Foloni, J. S. S., Calonego, J. C., Catuchi, T. A., Belleggia, N. A., Tiritan, C. S., \& Barbosa, A. D. M. (2014) Cultivares de milho em diferentes populações de plantas com espaçamento reduzido na safrinha. Revista Brasileira de Milho e Sorgo, 13(3), 312-325. doi: 10.18512/1980-6477/rbms.v13n3p312-325

Gross, M. R., Von Pinho, R. G., \& Brito, A. H. de. (2006). Nitrogen fertilization, sowing rate and interrow spacing in corn crop in no-tillage system. Ciência e Agrotecnologia, 30(5), 387-393.

Johnson, G. A., Hoverstad, T. R., \& Greenwald, R. E. (1998). Integrated weed managament using narrow corn row spacing, herbicides, and cultivation. Agronomy Journal, 90(1), 40-46. doi: 10.2134/agron j1998.00021962009000010008x

Kappes, C., Andrade, J. A. C., Arf, O., Oliveira, A. C., Arf, M. V., \& Ferreira, J. P. (2011) Desempenho de híbridos de milho em diferentes arranjos espaciais de plantas. Bragantia, 70(2), 334-343. doi: 10.1590/ S0006-87052011000200012

Kopper, C. V., Meert, L., Krenski, A., Borghi, W. A., Oliveira, A. M., Neto, \& Figueiredo, A. S. T. (2017). Produtividade de milho segunda safra em função de diferentes velocidades de semeadura e densidade de plantas. Pesquisa Agropecuária Pernambucana, 22, e201701. doi: 10.12661/pap.2017.003

Marchão, R. L., Brasil, E. M., Duarte, J. B., Guimarães, C. M., \& Gomes, J. A. (2005). Densidade de plantas e características agronômicas de híbridos de milho sob espaçamento reduzido entre linhas. Pesquisa Agropecuária Tropical, 35(2), 93-101. doi: 10.5216/ pat.v35i2.2256

Modolo, A. J., Carnieletto, R., Kolling, E., Trogello, E., \& Sgarbossa, M. (2010). Desempenho de híbridos de milho na Região Sudoeste do Paraná sob diferentes espaçamentos entrelinhas. Ciência Agronômica, 41(2), 435-441. 
Moreira, A., Moraes, L. A. C., Schroth, G., \& Mandarino, J. M. G. (2015). Effect of nitrogen, row spacing, and plant density on yield, yield components, and plant physiology in soybean-wheat intercropping. Agronomy Journal, 107(6), 2162-2170. doi: 10.2134/ agronj 15.0121

Sangoi, L., Almeida, M. L., Ender, M., Guidolin, A.F., \& Konflanz, V. A. (2001). Nitrogen fertilization impact on agronomic traits of maize hybrids released at diferent decades. Pesquisa Agropecuária Brasileira, 36(5), 757-764. doi: 10.1590/S0100204X2001000500005

Sangoi, L., Silva, P. R. F., \& Argenta, G. (2010). Estratégias de manejo do arranjo de plantas para aumentar o rendimento de grãos do milho. Lages: Graphel.

Schmitt, A. (2014). Arranjo de plantas para maximizar o desempenho agronômico do milho em ambientes de alto manejo. Tese de doutorado, Universidade do Estado de Santa Catarina, Centro de Ciências Agroveterinárias, Lages, Brasil.

Silva, A. G., Teixeira, I. R., Martins, P. D. S., \& Simon, G. A., \& Francischini, R. (2014). Desempenho agronômico e econômico de híbridos de milho na safrinha.RevistaAgro@mbiente, 8(2),261-271. doi: 10.18227/1982-8470ragro.v8i2.1706
Souza, E. F. C., \& Soratto, R. P. S. (2006). Efeito de fontes e doses de nitrogênio em cobertura, no milho safrinha, em plantio direto. Revista Brasileira de Milho e Sorgo, 5(3), 395-405. doi: 10.18512/19806477/rbms.v5n3p395-405

Stacciarini, T. C. V., Castro, P. H. C., Borges, M. A., Guerin, H. F., Moraes, P. A. C., \& Gotardo, M. (2010). Avaliação de caracteres agronômicos da cultura do milho mediante a redução do espaçamento entre linhas e aumento da densidade populacional. Revista Ceres, 57(4), 516-519. doi: 10.1590/S0034737X2010000400012

Taiz, L., \& Zeiger, E. (2017). Fisiologia vegetal (6a ed.). Porto Alegre: Artmed.

Torres, F. E., Langhi, G., Teodoro, P. E., Ribeiro, L. P., Corrêa, C. C. G., \& Oliveira, E. P. (2013). Desempenho de híbridos de milho cultivados em diferentes espaçamentos na região do Cerrado brasileiro. Revista de Ciências Agrárias, 36(4), 411416. 